\title{
Antitrypanosomal effect of methanolic extract of Zingiber officinale (ginger) on Trypanosoma brucei brucei-infected Wistar mice
}

\author{
P. I. Kobo, P. J. Erin, M. M. Suleiman, H. Aliyu, M. Tauheed, S. Muftau and M. Mamman \\ Department of Veterinary Pharmacology and Toxicology, Faculty of Veterinary Medicine, \\ Ahmadu Bello University, Zaria, Nigeria. \\ Corresponding author: Patricia Ishaku Kobo, e-mail: patriciakobo@yahoo.com, \\ PJE: pius4u2c@yahoo.com, MMS: mohsulai@yahoo.com, HA: haliyu63@gmail.com, MT: mtauheed40@yahoo.com, \\ SM: shittumuftau@yahoo.com, MM: mammanm@hotmail.com \\ Received: 15-05-2014, Revised: 18-08-2014, Accepted: 24-08-2014, Published online: 05-10-2014
}

doi: 10.14202/vetworld.2014.770-775. How to cite this article: Kobo PI, Erin PJ, Suleiman MM, Aliyu H, Tauheed M, Muftau S, Mamman M (2014)Antitrypanosomal effect of methanolic extract of Zingiber officinale (ginger) on Trypanosoma brucei brucei-infected Wistar mice, Veterinary World 7(10): 770-775.

\begin{abstract}
Aim: The study was carried out to determine the in vivo antitrypanosomal effect of methanolic extract of Zingiber officinale (ginger) in Trypanosoma brucei brucei-infected mice.

Materials and Methods: Twenty-five mice were randomly allocated into five groups of five animals each. Group I and II were given Tween $80(1 \mathrm{ml} / \mathrm{kg})$ and diminazene aceturate $(3.5 \mathrm{mg} / \mathrm{kg})$ to serve as untreated and treated controls, respectively. Groups III-V received the extract at 200, 400 and $800 \mathrm{mg} / \mathrm{kg}$ body weight, respectively. All treatments were given for 6 consecutive days and through the oral route. The mean body weight, mean survival period and daily level of parasitaemia were evaluated.
\end{abstract}

Results: Acute toxicity showed the extract to be relatively safe. There was an insignificant increase in body weight and survival rate of mice treated with the extract. The level of parasitaemia in the extract treated groups was decreased.

Conclusion: This study shows the in vivo potential of methanolic extract of $Z$. officinale in the treatment of trypanosomiasis.

Keywords: parasitaemia, survival rate, trypanosomiasis, Zingiber officinale.

\section{I ntroduction}

African animal trypanosomiasis remains a disease with unsatisfactory medical control [1]. To date, its control relies principally on the use of chemotherapeutic and chemoprophylactic agents such as; diminazene (DZ) aceturate, homidium, and isometamidium [2-4]. However, this practice has certain drawbacks that include the development of resistance to the drugs by the parasite and toxicity to the hosts [1-6]. Trypanosomes have the glycoprotein that is encoded by genes that are antigenically distinct thus making the parasite able to engage an immune-evasive process of antigenic variation [3,7]. Owing to this process, the prospect of vaccine development are poor, making drug the only viable management option, however they have some limitations $[8,9]$. Thus, the search for new drugs and formulations which are safe, affordable, and effective against both early and late stages of the disease, has been recommended $[6,10]$.

Since drugs derived from medicinal plants are natural and have been argued to be effective and safe, moreover among indigene of trypanosome endemic areas, there are claims of medicinal plants with therapeutic activities [6,11]. Zingiber officinale (ginger) has been widely used around the world as food and

Copyright: The authors. This article is an open access article licensed under the terms of the Creative Commons Attributin License (http:// creative commons.org/licenses/by/2.0) which permits unrestricted use, distribution and reproduction in any medium, provided the work is properly cited. as a spice [12-14]. It is considered a safe herbal medicine with only a few and insignificant adverse/side-effects $[15,16]$. Several authors have shown that ginger is endowed with strong in vitro and in vivo anti-oxidant properties [12,14,15].

Increasing evidence demonstrates that the oxidative stress plays an important etiologic role in the pathogenesis of African sleeping sickness $[1,17,18]$ Oxidant stress arises when there is an imbalance between radical-generating and radical-scavenging activities; it may, therefore, cause an increase in the formation of oxidative products $[4,19,20]$. Infection caused by Trypanosoma brucei group of parasites have been shown to alter the antioxidant defense of the host [21-26]. Ginger being a strong antioxidant will either mitigate or prevent the generation of free radicals $[12,14]$. such as those generated by trypanosomes [27]. Ginger has been reported to have many pharmacological activities, including anticancer, anti-inflammatory, antioxidant, anthelmintic, antiemetic, immunomodulatory and nephroprotective effects $[12,14,28]$. However, information on the antitrypanosomal effect of $Z$. officinale extract is still scanty. Therefore, the present study was carried out to evaluate in vivo antitrypanosomal effect of methanolic extract of Z. officinale in mice infected with T. brucei brucei.

\section{Materials and Methods}

\section{Ethical approval}

All experimental protocols were approved and conducted with strict adherence to guidelines of the Institutional Animal Care and Use Committee of 
Ahmadu Bello University, Zaria, Nigeria, which are in accordance with the principles of the laboratory animal care [29].

\section{Plant material}

Fresh ginger rhizomes were purchased from Zaria, Nigeria and were authenticated at the Herbarium, Department of Biological Sciences, Ahmadu Bello University, Nigeria. Voucher specimen number 2261 was deposited at the herbarium.

\section{Preparation of crude extract}

The ginger rhizomes were washed, sliced and dried at room temperature and pressure for 7 days. The dried ginger was made into powder using mortar and pestle. The powder (300 g) was extracted by maceration using methanol (900 ml) (analytical grade) at ratio of 1:3 of powdered ginger and methanol. The mixture of the powdered ginger and methanol were allowed to stand in a percolator for $48 \mathrm{~h}$, thereafter, the extract was collected and about $60 \%$ of the initial volume of methanol was further added and allowed to stand for $24 \mathrm{~h}$. The extracts were pooled together and concentrated in vacuo at $50-55^{\circ} \mathrm{C}$. The dried extract was dissolved in Tween 80 for the toxicity and pharmacological trials.

\section{Phytochemical screening}

The methanolic extract was subjected to phytochemical screening employing the standard screening method of Silva et al. [30].

\section{Determination of the acute lethal toxicity}

Determination of median $\mathrm{s}\left(\mathrm{LD}_{50}\right)$ was carried out according to the method of Lorke [31]. A total of 12 mice weighing between 16 and $30 \mathrm{~g}$ were used during the first and second trials. In the first phase, 9 mice were randomly divided into three groups of 3 mice each and treated orally with the plant extract at $10 \mathrm{mg} / \mathrm{kg}, 100 \mathrm{mg} / \mathrm{kg}$ and $1000 \mathrm{mg} / \mathrm{kg}$, respectively. The second phase was conducted using another set of 3 mice randomly divided into 3 groups of 1 mouse each and treated orally with $1600 \mathrm{mg} / \mathrm{kg}, 2900 \mathrm{mg} / \mathrm{kg}$ and $5000 \mathrm{mg} / \mathrm{kg}$, respectively. These doses were chosen based on the earlier results that showed no toxic effect of the initial doses used. Similarly, after the second trial, no mortality was recorded.

\section{Experimental animals}

A total of 25 adult male mice weighing between 16 and $30 \mathrm{~g}$ were used for this experiment. They were obtained from the Animal House, Department of Veterinary Pharmacology and Toxicology, Ahmadu Bello University, Zaria. They were allowed to acclimatize for 14 days in the research laboratory of the Department, where the experiment was conducted. The rats were housed under standard hygienic conditions in plastic cages with wood shavings as bedding, which was changed every week. The rats were kept at the ambient temperature of $24-26^{\circ} \mathrm{C}$ and relative humidity of 70-80\%, with $12 \mathrm{~h}$ /day light period. They were given access to rat pellets and water ad libitum.

\section{Trypanosome parasite}

T. brucei brucei (Federi strain) used for this study was obtained from Nigerian Institute for Trypanosomiasis Research, Vom, Plateau State, Nigeria. The parasite was maintained by serial passages in donor rats. parasitemia was monitored daily by preparing a wet mount and viewed under a light microscope (Olympus ${ }^{\circledR} \mathrm{CH} 23$, Germany) at $\times 400$ magnification.

\section{I noculation of rats}

The infected blood from a donor rat was collected at peak parasitemia and diluted with physiological saline, which was inoculated into the peritoneal cavity of the infected rats. Each rat was inoculated with $1 \mathrm{ml}$ of blood containing approximately $10^{6}$ cells/ml [32,33].

\section{Experimental design}

25 mice were randomly grouped into five groups (I, II, III, IV and V) of 5 animals each. All the Groups (I-V) were intraperitoneally infected with $T$. brucei brucei $\left(10^{6}\right.$ cells $\left./ \mathrm{ml}\right)$. Group I and II were administered orally Tween $80(1 \mathrm{ml} / \mathrm{kg})$ and $\mathrm{DZ}$ aceturate (3.5 mg/kg) intraperitoneally to serve as untreated and treated controls, respectively, while Groups III-V received the extract orally at daily doses of 200, 400 and $800 \mathrm{mg} / \mathrm{kg}$ body weight respectively for 6 days. Body weight was measured daily using a digital weighing balance, while parasitemia was monitored using the rapid matching method of Herbert and Lumsden [34].

\section{Statistical analysis}

Data obtained were expressed as mean \pm standard error of maen (SEM), and subjected to one-way analysis of variance, followed by Tukey's multiple comparison post-hoc test, using GraphPad Prism version 4.0 for windows (GraphPad Software, San Diego, California, USA). $\mathrm{p}<0.05$ were considered as significant.

\section{Results}

\section{Acute toxicity test}

The overall acute toxicity outcome $\left(\mathrm{LD}_{50}\right)$ is shown in Table-1. No animal died within $24 \mathrm{~h}$ after treatment with the plant extract at dose levels up to $5000 \mathrm{mg} / \mathrm{kg}$.

Table-1: Acute toxic effect of Zingiber officinale CME administered orally to mice.

\begin{tabular}{lcccc}
\hline Extract Experiment & $\begin{array}{c}\text { Dose } \\
\text { ( } \mathbf{m g} / \mathbf{k g})\end{array}$ & $\begin{array}{c}\text { Number of } \\
\text { animals used }\end{array}$ & $\begin{array}{c}\text { Number } \\
\text { dead }\end{array}$ \\
\hline $\mathrm{CME}$ & Phase 1 & 10 & 3 & 0 \\
& & 100 & 3 & 0 \\
$\mathrm{CME}$ & Phase 2 & 1000 & 3 & 0 \\
& & 1600 & 1 & 0 \\
& & 2900 & 1 & 0 \\
& & 5000 & 1 & 0 \\
\hline
\end{tabular}

$\mathrm{CME}=$ Crude methanol extract, $\mathbf{Z}$. officinale=Zingiber officinale 


\section{Phytochemical screening}

The phytochemical screening revealed the presence of alkaloid, steroids, phlobotannins, flavanoids, glycosides, saponins, tannin, terpenoids.

Effect of treatments on body weight changes in mice

Figure-1 shows the effect of treatments on the body weight changes of mice at days 0 and 5 of the experiment. An insignificant $(\mathrm{p}>0.05)$ decrease in body weight was recorded in Group I (untreated control) at day 5 when compared with day 0. Mice in Groups II (treated control), III (200 mg/kg ginger extract [GE]), IV (400 mg/kg GE) and V (800 mg/kg $\mathrm{GE})$ showed an insignificant $(\mathrm{p}>0.05)$ increase in body weight at day 5 compared to day 0 .

\section{Effect of treatments on the survival rate of mice}

The effect of treatments on the survival rate of mice is shown in Figure-2.

There was a relative decrease in the survival rate of mice in Group I when compared to Groups III, IV and V. A significant $(\mathrm{p}<0.05)$ increase was observed in the survival time of mice in Group II when compared to Groups I and III.

\section{Effect of treatments on the level of parasitemia}

Although it was not significant $(p<0.05)$, the level of parasitemia was relatively lower in Groups III, IV and V mice in comparison to Group I. The level of parasitemia in Group II mice, dropped to zero at day 6 post-infection (Figure-3).

\section{Discussion}

Phytochemical screening of methanolic extract of $Z$. officinale revealed the presence of alkaloids, steroids, phlobatannins, flavonoids, glycosides, saponins, tannins and terpenoids. The trypanocidal property of the extract may be due to the action of one or more constituents present in the plant. Several workers have either identified or isolated tannins or phenolic compounds [35], flavonoids and alkaloids [20] in plants that showed trypanocidal activities. Perhaps, the trypanosomal effect of the extract may be due to one or more of these secondary metabolites.

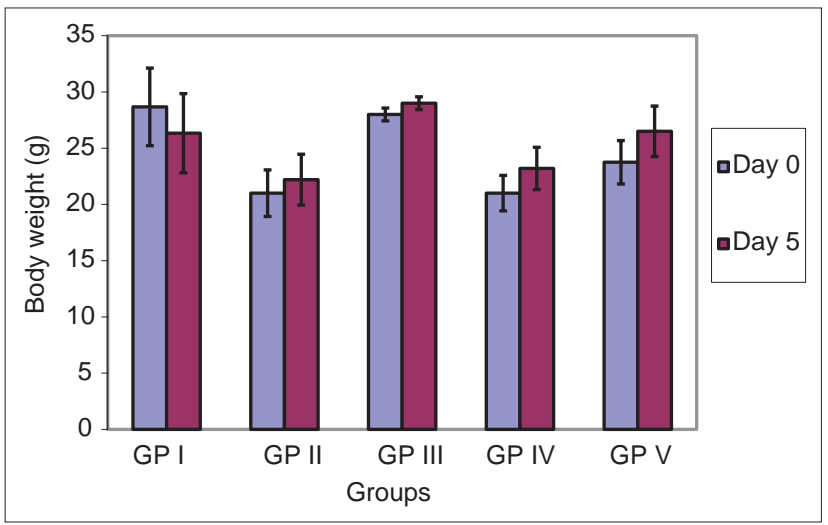

Figure-1: Effect of treatment with diminazene aceturate and ginger extract on the body weight of mice at day 0 and 5 of the experiment.
The result of acute toxicity test $\left(\mathrm{LD}_{50}\right)$ is shown in Table-1. The extract did not produce mortality when given at a dose of up to $5 \mathrm{~g} / \mathrm{kg}$ by oral route, indicating that the extract is relatively non-toxic to mice. This agrees with the report of Ali et al. [15] where ginger was demonstrated to be a safe herbal medicine with only few and insignificant adverse/ side effects.

A relative decrease was observed in the body weight of mice in Group I (untreated) at day 5 of the experiment when compared to day 0 (Figure-1). This is consistent with the findings of Alli et al. [36] which showed that infection with T. brucei brucei was associated with weight loss.

The increase in body weight observed in animals treated with DZ aceturate and GE demonstrated that DZ and GE protected the rats from trypanosome-induced decrease in body weight. The effect of DZ and GE on the body weight may be due to the trypanocidal effect of DZ and the antioxidant effect of GE that reduced the parasite burden in the body.

The relative increase (Figure-2) in the survival time of mice treated with $400 \mathrm{mg} / \mathrm{kg}$ and $800 \mathrm{mg} / \mathrm{kg}$ of GE suggests that the extract could

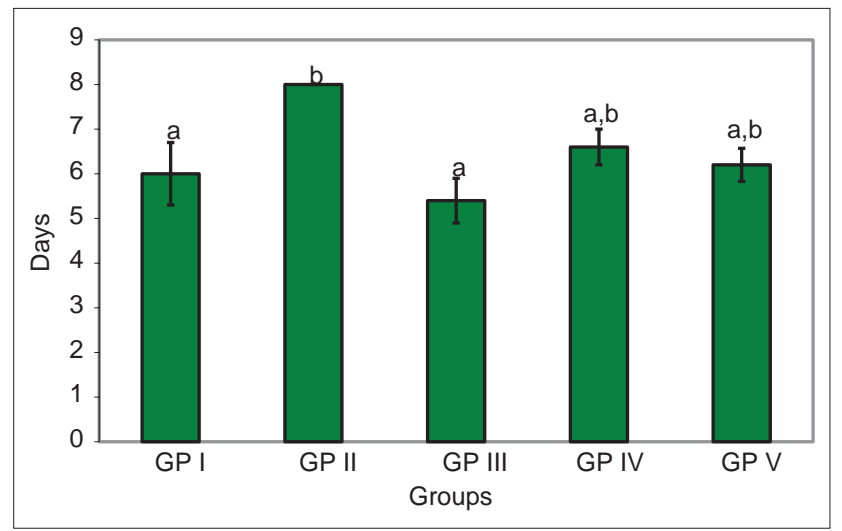

Figure-2: Effect of treatments with diminazene aceturate and ginger extract on the survival rate of mice experimentally infected with Trypanosoma brucei brucei. a,bMeans with different superscript letters are statistically different $(p<0.05)$. Values are mean \pm standard error of the mean of 3 animals per group.

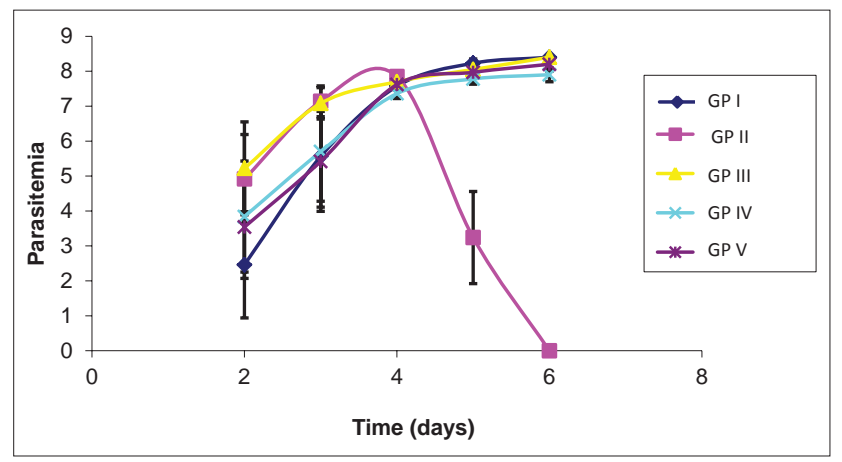

Figure-3: Effect of treatments with diminazene aceturate and ginger extract on the level of parasitaemia in mice experimentally infected with Trypanosoma brucei brucei. 
be useful in the management of African trypanosomiasis. This finding agrees with other works that have shown that plant extracts containing polyphenols have the ability to increase the survival of mice infected with $T$. brucei $[7,36]$. Trypanosomiasis is a disease whose pathological effects are initiated through the release of cytokines and nitric oxide [26,37]. Polyphenols have been shown to attenuate cytokine and nitric oxide-induced inflammation [7,37], probably due to their reactive oxygen species (ROS) scavenging ability. Therefore, we may speculate that the ability of the extract to increase the survival of mice in this study may be due to their ability to aid antioxidant defense system and reduce oxidative stress by protecting the defense system against the damaging effects of ROS. The survival time of mice treated with DZ was significantly increased compared to the untreated control. This may be due to the ability of the drug to eliminate the parasites from the blood [38].

The prepatent period of 2 days (Figure-3) observed in the present study disagree with earlier findings [24] that reported a prepatent period of 4-5 days in mice infected with T. brucei. The parasitemia observed in this experiment rose progressively without any period of drop in all the treatment groups, which indicates an acute phase of the disease, except for the DZ treated group where parasitemia dropped to 0 at day 6 post infection. In another study, a similar observation was made with this strain of parasite [39]. Treatment with GE did not affect the onset of parasitemia but reduced the level of parasitemia when compared with untreated control. Several researchers made similar observations on reduction in parasitemia and concluded that high parasite load could mask the efficacy of crude extract $[40,41]$. This could be responsible for the insignificant decrease in the level of parasitaemia that was observed in the groups treated with GE. More so, the efficacy of crude extracts may also require administration via parenteral route. Reduced efficacy of crude extract of $Z$. officinale could also be due to enzymatic inactivation of active compounds or impaired absorption from the gut or both $[40,41]$. The mechanism of the extract trypanocidal action was not determined. However, Sepulveda-Boza and Cassels [42] reported that many natural products exhibit their trypanocidal activity by virtue of their interference with the redox balance of the parasites acting either on the respiratory chain or on the cellular defenses against oxidative stress. This is because natural products possess structures capable of generating radicals that may cause peroxidative damage to enzymes that are very sensitive to alteration in redox balance. It is also known that some agents also act by binding with the kinetoplast DNA of trypanosomes [43].

\section{Conclusion}

Administration of methanolic extract of Z. officinale increased body weight and survival time of mice infected with $T$. brucei brucei. It also reduced the level of parasitemia in infected mice. However, further study is required to determine the active constituent in the extract and its mode of action.

\section{Authors' Contributions}

MMS and MM implemented the study design, drafted and revised the manuscript. PIK, PJE, HA and MT carried out the laboratory experimentation and drafted the manuscript. MS carried out the statistical analysis. All authors read and approved the final manuscript.

\section{Acknowledgements}

The authors are grateful to Mr. Emmanuel Nwosu and Sani Abdulrazaq of the Department of Veterinary Physiology and Mr. Dennis Otie of the Department of Veterinary Pharmacology and Toxicology, for their technical assistance during the course of this work. The authors are thankful to The Department of Veterinary Pharmacology and Toxicology, Faculty of Veterinary Medicine, Ahmadu Bello University, Zaria, Nigeria for providing necessary facilities. This study was sponsored by the authors.

\section{Competing I nterests}

They authors declare that they have no competing interests.

\section{References}

1. Edoga, C.O., Njoku, O.O. and Okeke, J.J. (2013) The effect of aqueous extracts of Moringa oleifera leaves on haematological parameters of Trypanosoma brucei-infected rats. Res. J. Animal. Vet. Fish. Sci., 1(16): 15-17.

2. Ameen, S.A. (2013) Antitrypanosomal activities of natural honey in Trypanosoma congolense-infected Wistar rats. Vet. Res., 6(1): 10-14.

3. Brian, T.E., Melvin, D.D., Joann, M.T., Conrad, L.E. and David, M.E. (2010) Calflagin inhibition prolongs host survival and suppresses parasitaemia in Trypanosoma brucei infection. Eukaryot. Cell., 9(6): 934-942.

4. Ajakaiye, J.J., Mazadu, R.M., Benjamin, M.S., Bizi, L.R., Shuaibu, Y., Kugu, B.A., Mohammed, B. and Muhammad, A.A. (2013) Effects of dietary vitamins $\mathrm{C}$ and $\mathrm{E}$ oral administration on body temperature, body weight and haematological parametres in Wistar Rats infected with $T$. brucei brucei (Federe strain) during the hot rainy season. Int. Res. J. Pharm. Pharmacol., 3(7): 105-111.

5. Eze, J.I., Okeke, M.C., Ngene, A.A., Omeje, J.N. and Abonyi, F.O. (2013) Effects of dietary selenium supplementation on parasitaemia, anaemia and serum proteins of Trypanosoma brucei brucei-infected rats. Exp. Parasitol., 135: 331-336.

6. Lawal, M., Oboh, A. and Malann, Y.D. (2013) Antitrypanosomal activity of the ethanolic leaf extract of Senna occidentalis (Fabaceae) on Tyrpanosoma brucei brucei-infected mice. Int. J. Basic. Appl. Sci., 2(1): 32-37.

7. Ngure, R.M., Ongeri, B., Karori, S.M., Wachira, W., Maathai, R.G., Kibugi, J.K. and Wachira, F.N. (2009) 
Antitrypanosomal effects of Azadirachta indica (neem) extract on Trypanosoma brucei rhodesiens -infected mice. Engl. J. Med., 14: 2-9.

8. Samdi, S.M., Abenga, J.N., Attahir, A., Wayo, B.M., Sumayin, H.M., Haruna, M.K., Jijitar, A.M., Ogunwale, R.T., Ramatu, R.N. and Bizi, R.L. (2010) Constraints in the control of African trypanosomosis: The prevailing factors in Kurmin - Kaduna, Northern Nigeria. Int. J. Anim. Vet. Adv., 2(1): 31-36.

9. Prathalingham, S.R., Wilkison, S.R., Horn, D. and Kelly, J.M. (2007) Deletion of the Trypanosoma brucei superoxide dismutase gene sodb1 increases sensitivity to nifurtimox and benznidazole. Antimicrob. Agents. Chemother., 51(2): 755-758.

10. Pink, R., Hudson, A., Mouries, M.A. and Bending, M. (2005) Opportunities and challenges in antiparasitic drug discovery. Nat. Rev. Drug Discov., 49: 727-740.

11. Atawodi, S.E., Ameh, D.A., Ibrahim, S., Andrew, J.N., Nzelibe, H.C., Onyike, E., Anigo, K.M. and Sallau, A.B. (2002) Indigenous knowledge system for treatment of trypanosomiasis in Kaduna state of Nigeria. J. Ethnopharmacol., 79: 279-282.

12. Haniadka, R., Saldanha, E., Sunita, V., Palatty, P.L., Fayad, R. and Baliga, M.S. (2013) A review of the gastroprotective effects of ginger (Zingiber officinale Roscoe). Food Funct., 4(6): 845-855.

13. Sepide, M., Alireza, O., Majid, M., Vahide, E.A. and Laleh, P. (2013) Anti-inflammatory effects of Zingiber officinale in type 2 diabetic patients. Adv. Pharm. Bull., 3(2): 273-276.

14. Daleya, A.B., Mohammed, F.H., Nor, A.A., Elham, R., Maryam, H. and Mahmood, A.A. (2013) In vivo evaluation of ethanolic extract of Zingiber officinale rhizomes for its protective effect against liver cirrhosis. Biomed. Res. Int. Available from: http://www.dx.doi. org/10.1155/2013/918460. [Last accessed on 2013 April 23].

15. Ali, B.H., Blunden, G., Tanira, M.O. and Nemmar, A. (2008) Some phytochemical, pharmacological and toxicological properties of ginger (Zingiber officinale Roscoe): A review of recent research. Food Chem. Toxicol., 46: 409-420.

16. Bhargava S. (2012) Zingiber Officinale: Chemical and phytochemical screening and evaluation of its antimicrobial activities. J. Chem. Pharm. Res., 4(1): 360-364.

17. Ogunsanmi, A.O. and Taiwo, V.O. (2001) Pathobiochemical mechanisms involved in the controlof the caused by Trypanosoma congolense in Africa grey duiker (Sylvicapra grimmia). Vet. Parasitol., 96: 51-63.

18. Kobo, P.I., Ayo, J.O., Aluwong, A., Zezi, A.U., Maikai, V. and Ambali, S.F. (2014) Flavonoid mixture ameliorates increase in erythrocyte osmotic fragility and malondialdehyde concentration induced by Trypanosoma brucei brucei-infection in Wistar rats. Res. Vet. Sci., 96: 139-142.

19. Saleh, M.A., Bassam, M.A. and Sanousi, S.A. (2009) Oxidative stress in blood of camels (Camelus dromedaries) naturally infected with Trypanosoma evansi. Vet. Parasitol., 162: 192-199.

20. Umar, I.A., Ndidi, U.S., Mohammed, A., Anaedum, V.C., Zambuk, U.U., Umar, A.U. and Bello, M.A. (2014) In vitro antitrypanosomal activity, antioxidant property and phytochemical constituents of aqueous extracts of nine Nigerian medicinal plants. Asian Pac. J. Trop. Dis., 4(5): 348-355.

21. Igbokwe, I.O. (1994) Mechanism of cellular injury in African trypanosomiasis. Vet. Bull., 64(7): 615-617.

22. Igbokwe, I.O., Umar, I.A., Omage, J.J., Ibrahim, N.D.G., Kadima, K.B., Obagaiye, O.K., Saror, D.I. and Esievo, K.A.N. (1996) Effect of acute Trypanosoma vivax infection on cattle erythrocyte glutathione and susceptibility to in vitro peroxidation. Vet. Parasitol., 63: 215-24.

23. Omer, O.H., Mousa, H.M. and Al-Wabel, N. (2007) Study on antioxidant status of rats experimentally infected with
Trypanosoma evansi. Vet. Parasitol., 145: 142-145.

24. Umar, I.A., Ogenyi, E., Okodaso, D., Kimeng, E., Stancheva, G.I., Omage, J.J., Isah, S. and Ibrahim, M.A. (2007) Amelioration of anaemia and organ damage by combined intraperitoneal administration of vitamins $A$ and $C$ to Typanosoma brucei brucei -infected rats. Afr. J. Biotechnol., 6(18): 2083-2086.

25. Umar, I.A., Toma, I., Akombum, C.A., Nnaji, C.J., Mahdi, M.A., Gidado, A., Igbokwe, I. O. and Buratai, L.B. (2010) The role of intraperitoneally administered vitamin C during Trypanosoma congolense infection of rabbits. Afr. J. Biotechnol., 9(32): 5224-5228.

26. Serem, E.K., Mburu, J., Mdachi, R., Korir, S., Kibugu, J., Kagira, J. and Ngure, R. (2013) Effects of crude extracts of Solanum nigrum on the liver pathology and survival time in Trypanosoma brucei rhodesiense-infected mice. Sci. J. Microb., 2013: 1-7.

27. Shaba, P., Pandey, N.N., Sharma, O.P., Rao, J.R. and Singh, R.K. (2011) Anti-trypanosomal potential of methanolic extract of Calotropis gigantea leaves against Trypanosoma evansi and its cytotoxicity. Int. J. Bio. Resour. Stress Manage., 73: 121-124.

28. Adel, A., Basant, M.M., Ayman, M.M., Mohamed, A.A. and Mohamed, I.Z. (2013) Beneficial therapeutic effects of Nigella sativa and/or Zingiber officinale in HCV patients in Egypt. EXCLI. J., 12: 943-955.

29. Canadian Council on Animal Care Guide (CACC). $2^{\text {nd }}$ ed., Vol. 1. 1993. Available from: http://www.ccac.ca/en-/standards/guidelines/. [Last accessed on 2011 Jun 17, 4 pm.].

30. Silva, G.L., Lee, I. and Kinghorn, A.D. (1998) Special problems with the extraction of plants. In: Cannel R.J.P., editor. Natural Products Isolation. Vol. 1. Human Press, Totowa. New Jersey. p354-360.

31. Lorke, D. (1983) A new approach to practical acute toxicity testing. Arch. Toxicol., 54: 275-287.

32. Ekanem, J.T. and Yusuf, O.K. (2005) Activities of alkaline phosphatase, glutamate oxaloacetate transaminase and glutamate pyruvate transaminase in liver and serum of Trypanosoma brucei - infected rats treated with honey. Biokemistri., 17: 185-191.

33. Ekanem, J.T., Majolagbe, O.R., Sulaiman, F.A. and Muhammad, N.O. (2006) Effects of honey supplemented diet on the parasitaemia and some enzymes of Trypanosoma brucei - infected rats. Afr. J. Biotech., 5: 1557-1561.

34. Herbert, W.J. and Lumsden, W.H.R. (1976) Trypanosoma brucei: A rapid "matching" method for estimating the host’s parasitaemia. Exp. Parasitol., 40: 427-431.

35. Shuaibu, M.N., Wuyep, P.T.A., Yanagi, T., Hirayama, K., Ichinose, A., Tanaka., T. and Isao, T.T. (2008) Trypanocidal activity of extracts and compounds from the stem bark of Anogeissus leiocarpus and Terminalia avicennoides. Parasitolology, 102(4): 697-703.

36. Alli, L.A., Okochi, V.I. and Adesokan, A.A. (2011) Antitrypanosomal activity and haematological effects of aqueous extract of leaves of Morinda lucida on Trypanosoma brucei brucei infected rats. Asian J. Pharm. Health Sci., 1: 111-115.

37. Karina, P., Jorge, M.A. and Marcelo, S.S. (2011) Induced cytokine network during experimental African trypanosomosis. Int. J. Interferon. Cytokine Mediator. Res., 3: $71-78$

38. Saba, A.B., Adedapo, A.A., Oyagbemi, A.T. and Odudu, Z.K. (2007) Laboratory evaluation of senative pair of diminazene aceturate and isometamedium chloride as combination therapy for animal trypanosomosis. Folia. Vet., 51(3-4): 169-174.

39. Umar, I.A., Toh, Z.A., Igbalajobi, F.I., Igbokwe, I.O. and Gidado, A. (1999) The effect of orally administered vitamins $\mathrm{C}$ and $\mathrm{E}$ on severity of anaemia in $T$ brucei infected rats. Trop. Vet., 18: 71-77.

40. Ekanem, J.T., Kolawole, O.M. and Abbah, O.C. (2008) Trypanocidal potential of methanolic extract of Bridelia 
ferruginea benth bark in Rattus novergicus. Afr. J. Biochem. Res., 2(2): 045-050.

41. Feyera, T., Terefe, G. and Shibeshi, W. (2014) Evaluation of in vivo antitrypanosomal activity of crude extracts of Artemisia abyssinica against a Trypanosoma congolense isolate. Complement. Altern. Med., 14: 117-125.
42. Sepulveda-Boza, S., and Cassels, B.K. (1996) Plant metabolites active against Trypanosoma cruzi. Plant Med., 62: 98-100. 43. Atawodi, S.E., Bulus, T., Ibrahim, S., Ameh, D.A., Nok, A.J., Mamman, M. and Galadima, M. (2003) In vitro trypanocidal effect of methanolic extract of some Nigerian Savannah plants. Afr. J. Biotechnol., 2(9): 317-321.

$* * * * * * * *$ 